\title{
Temperature response of photosynthetic capacity and carboxylase activity in Arctic marine phytoplankton
}

\author{
W. K. W. Li, J. C. Smith and T. Platt \\ Marine Ecology Laboratory, Bedford Institute of Oceanography, Dartmouth, Nova Scotia B2Y 4A2, Canada
}

\begin{abstract}
The temperature response of photosynthetic capacity was compared to that of 3 carboxylating enzymes in Arctic marine phytoplankton. Only the activity of ribulose-1,5-bisphosphate carboxylase (RuBPC) consistently exhibited an apparent activation energy equivalent to that of photosynthetic capacity. This is the first indication from field samples of phytoplankton that changes in the activity of RuBPC may be closely associated with changes in photosynthetic capacity. The maximum photosynthetic capacity attained by Arctic phytoplankton at a given in situ temperature appeared to increase from about $0.4 \mathrm{mg} \mathrm{C} \mathrm{mg} \mathrm{Chl} a^{-1} \mathrm{~h}^{-1}$ at $-1.5^{\circ} \mathrm{C}$ to an apparently constant value of about $2.0 \mathrm{mg} \mathrm{C} \mathrm{mg} \mathrm{Chl} a^{-1} \mathrm{~h}^{-1}$ at temperatures equal to and greater than $0.0^{\circ} \mathrm{C}$.
\end{abstract}

\section{INTRODUCTION}

The photosynthetic response and adaptation to temperature has been well studied in higher plants (Berry and Björkman, 1980; Patterson, 1980; Berry and Raison, 1981; Graham and Patterson, 1982) but not in unicellular algae (Eppley, 1972; Li, 1980). High latitude environments, especially marine ecosystems, are persistently cold. Phytoplankton inhabiting such systems are therefore particularly well-suited subjects for studies of photosynthesis at low temperatures.

In this paper, we examine the relation between photosynthetic capacity of Arctic phytoplankton and temperature of the water in situ. The measurements required to establish this relation are 'observations' in the sense that there is no interference with the metabolism of the cells except to sample and perform the measurements. These results pertain to the characteristics of the cells as they occur in nature. We also examine the short-term responses of photosynthetic capacity and carboxylase activities when cells are subjected to abrupt shifts in temperature. The results from these manipulative experiments pertain to the potential importance of the enzymes in the control of photosynthetic capacity at low temperatures.

\section{MATERIALS AND METHODS}

Photosynthetic rates were measured for phytoplankton sampled from the eastern Canadian subarctic (Labrador Sea) and Arctic (Baffin Bay, Lancaster Sound, Jones Sound, Smith Sound, Foxe Basin, Fury and Hecla Strait) during cruises to these areas from 1977 to 1981. Phytoplankton from various depths in the photic zone were collected in Niskin bottles. For each sample, the amount of $\mathrm{H}^{14} \mathrm{CO}_{3}{ }^{-}$taken up in $2 \mathrm{~h}$ was measured within a light gradient from about 1 to $800 \mathrm{~W} \mathrm{~m}^{-2}$ (PAR) in a temperature-controlled incubator, artificially illuminated by a $2,000 \mathrm{~W}$ tungsten-halogen floodlight. The temperature response of photosynthesis was determined on 10 occasions in the subarctic and on 12 occasions in the Arctic. For each sample, the photosynthesis-irradiance relation was established at each of four incubation temperatures. A detailed description of methods and the results of one such experiment have been published (Li and Platt, 1982). Photosynthetic capacity $\left(P_{m}^{B}\right)$ is defined as the rate of ${ }^{14} \mathrm{C}$ fixation $(\mathrm{P})$ measured at the irradiance resulting in the maximal (m) rate and normalized to phytoplankton biomass (B), expressed as the mass of chlorophyll a. Chlorophyll a was measured by the fluorometric 
technique of Yentsch and Menzel (1963) as modified by Holm-Hansen et al. (1965).

The activities of 3 carboxylating enzymes known to occur in marine algae (Appleby et al., 1980; Kremer, 1981) were also measured. Ribulose-1,5-bisphosphate carboxylase (RuBPC, E.C.4.1.1.39) and phosphoenolpyruvate carboxylase (PEPC, E.C.4.1.1.31) activities were determined radiometrically as described by Smith et al. (1983) by measuring the rate of incorporation of ${ }^{14} \mathrm{CO}_{2}$ (RUBPC) and $\mathrm{H}^{14} \mathrm{CO}_{3}{ }^{-}$(PEPC) into acid stable products by permeabilized cells in vivo. These assays were modified by the addition of L- $\alpha$-lysophos-

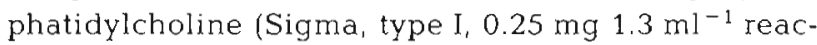
tion mixture), the reduction of the concentration of Tris buffer from 0.4 to $0.1 \mathrm{M}$ and the lowering of the $\mathrm{pH}$ from 8.0 to 7.5. Phosphoenolpyruvate carboxykinase (PEPCK, E.C.4.1.1.49) activity was determined in an assay system identical to that for PEPC except that $\mathrm{Mg}^{2+}$ was replaced by $\mathrm{Mn}^{2+}(2 \mathrm{mM})$ and ADP $(5 \mathrm{mM})$ The temperature responses of the enzymes were determined on numerous occasions by incubating the samples at seven different temperatures, although, for logistic reasons, only 4 or 5 experimental temperatures were used on the earliest cruise. Four experimental and 2 control replicates were determined for each enzyme at each temperature. The controls were not affected by temperature and their values may represent an absorption phenomenon or non-acid labile impurities in the ${ }^{14} \mathrm{C}$ stock solutions. A typical example both of the closeness of the replicates and of the goodness of the approximation of the temperature response of these enzymes to the Arrhenius formulation is that for RuBPC at station X228 from Foxe Basin. When the linear regression of the natural logarithm of RuBPC activity (dpm $\left.1^{-1} \mathrm{~h}^{-1}\right)$ against the reciprocal of the absolute temperature was calculated, the slope of the line was $-7268 \pm 315^{\circ} \mathrm{K}$ (SE) and the intercept was $33.866 \pm 1.103$ (SE). The correlation coefficient was -0.977 for 26 degrees of freedom, the probability of this arising by chance being less than $10^{-5}$

\section{RESULTS}

The relation between $\mathrm{P}_{\mathrm{m}}^{\mathrm{B}}$ of Arctic phytoplankton and in situ temperature is shown in Fig. 1 Most of the values for $\mathrm{P}_{\mathrm{m}}^{\mathrm{B}}$ are less than 2 and none greatly exceed $3 \mathrm{mg} \mathrm{C} \mathrm{mg} \mathrm{Chl} \mathrm{a}^{-1} \mathrm{~h}^{-1}$. In all cases here, the deviation of incubation temperature from that in situ was $\leq 1 \mathrm{C}^{\circ}$. The significance of the dashed line (Fig. 1) is discussed below

In experiments where the incubation temperature was manipulated away from that in situ, the temperature dependence of $\mathrm{P}_{\mathrm{m}}^{\mathrm{B}}$ and carboxylase activities (V) was expressed according to the Arrhenius equation as follows:

$$
\begin{aligned}
& Q=A e^{\left(-\frac{E_{a}}{R T}\right)} \\
& Q^{\prime}=A e^{\left(-\frac{E_{a}}{R T^{\prime}}\right)} \\
& \ln \left(\frac{Q^{\prime}}{Q}\right)=-\frac{E_{a}}{R}\left(\frac{1}{T^{\prime}}-\frac{1}{T}\right)
\end{aligned}
$$

where $\mathrm{Q}=$ either $\mathrm{P}_{\mathrm{m}}^{\mathrm{B}}$ or $\mathrm{V}$ at the absolute in situ temperature $\mathrm{T} ; \mathrm{Q}^{\prime}=$ either $\mathrm{P}_{\mathrm{m}}^{\mathrm{B}}$ or $\mathrm{V}$ at the absolute assay temperature $\mathrm{T}^{\prime} ; \mathrm{A}=\mathrm{a}$ constant $\mathrm{R}=$ gas constant $\mathrm{E}_{\mathrm{a}}=$ apparent activation energy. Equation (3) is simply the logarithmic transform of the ratio Q' : $Q$ (i.e. Eq. [2] divided by [1]). Equation (3) expresses rates relative to that in situ and thus allows experiments conducted on phytoplankton collected at various temperatures $\left(-1.5\right.$ to $\left.4.5^{\circ} \mathrm{C}\right)$ to be considered on a common basis. The validity of pooling data from separate experiments is indicated by the fact that $E_{a}$ for $P_{m}^{B}$ and for $V$ of any of the enzymes were statistically uncorrelated $(P \geq 0.2)$ with in situ temperature.

Plots of $\ln \left(\frac{Q^{\prime}}{\mathrm{Q}}\right)$ versus $\left(\frac{1}{T^{\prime}}-\frac{1}{T}\right)$ are shown for $P_{m}^{B}$

(Fig. 2). RuBPC (Fig. 3), PEPCK (Fig. 4), and PEPC (Fig. 5). On the basis of linear regressions of the data (Fig. 2 to 5) according to Eq. (3), the values of $\mathrm{E}_{\mathrm{a}} \pm$ standard error $\left(\mathrm{kcal} \mathrm{mol}^{-1}\right)$ were $16.9 \pm 0.85$ for $\mathrm{P}_{\mathrm{m}}^{\mathrm{B}} 17.3 \pm 0.67$ for RuBPC, $6.0 \pm 0.71$ for PEPCK and $7.8 \pm 1.03$ for

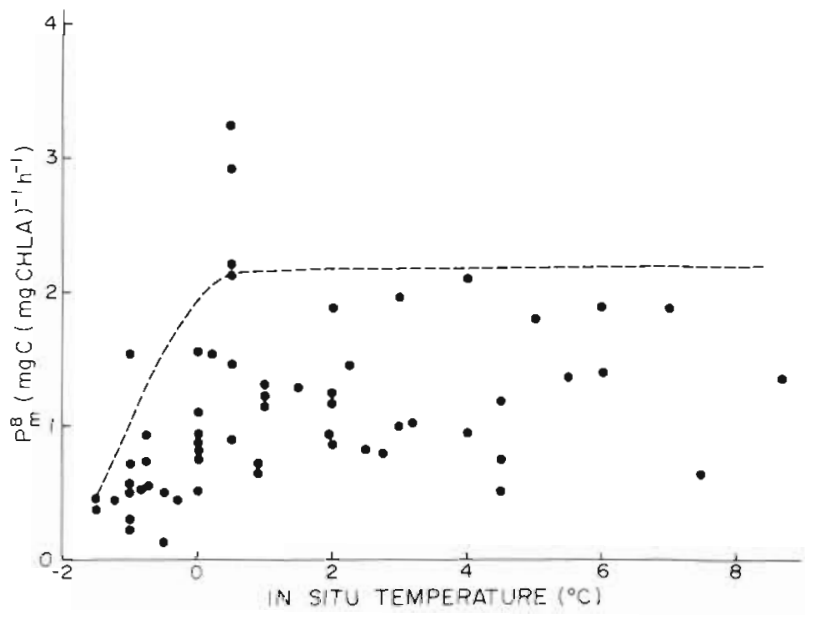

Fig. 1. Relation between photosynthetic capacity and in situ temperature for eastern Canadian Arctic marine phytoplankton. Temperatures during incubation were $\pm 1 \mathrm{C}^{\circ}$ of those in situ. See text for discussion of dashed curve 
Fig. 2. Modified Arrhenius plot (Equation 3) of photosynthetic capacjty in eastern Canadian Arctic marine phytoplankton

Fig. 3. Modified Arrhenius plot (Equation 3) of RuBPC activity in eastern Canadian Arctic marine phytoplankton

Fig. 4. Modified Arrhenius plot (Equation 3) of PEPCK activity in eastern Canadian Arctic marine phytoplankton.
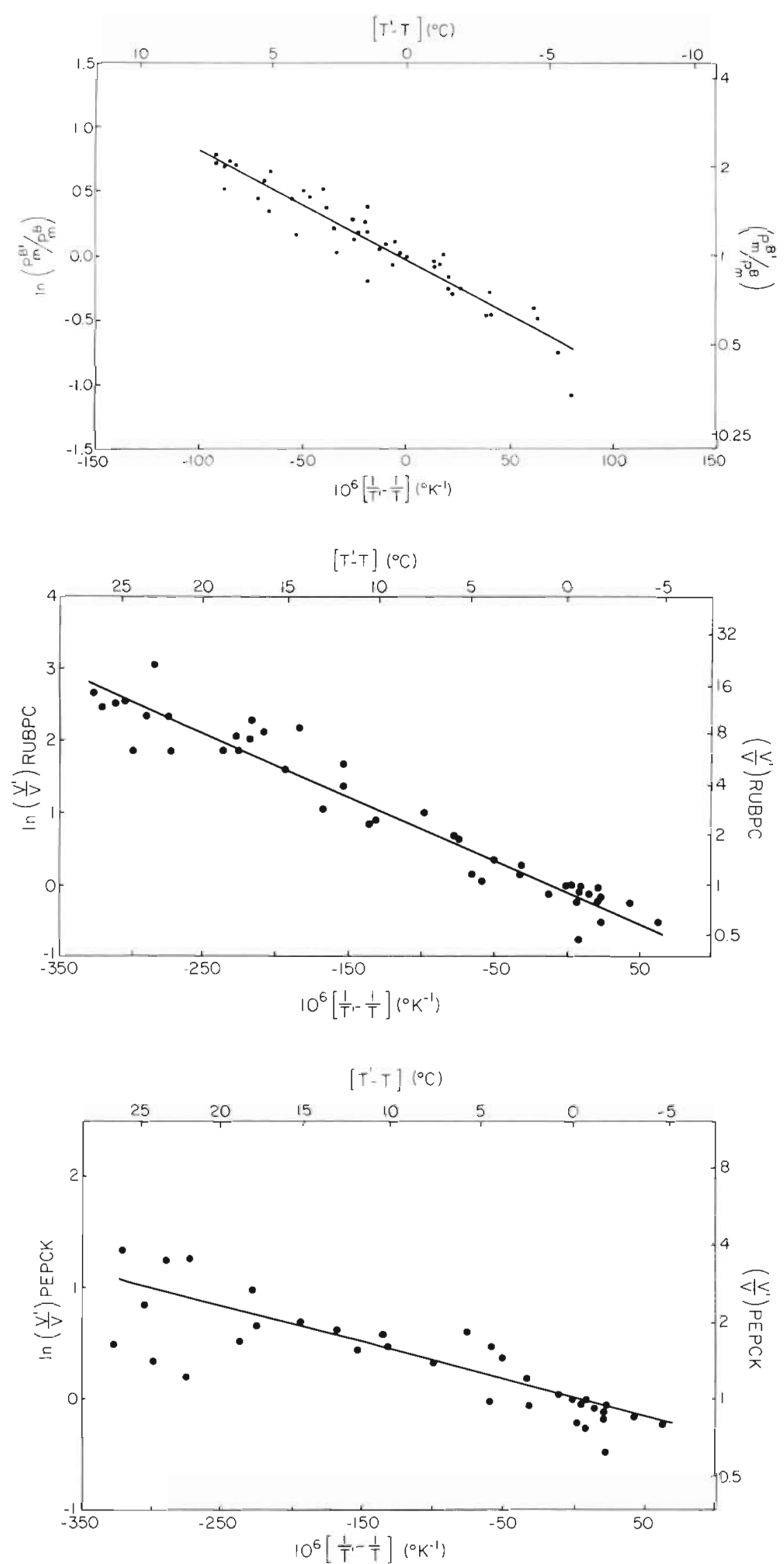


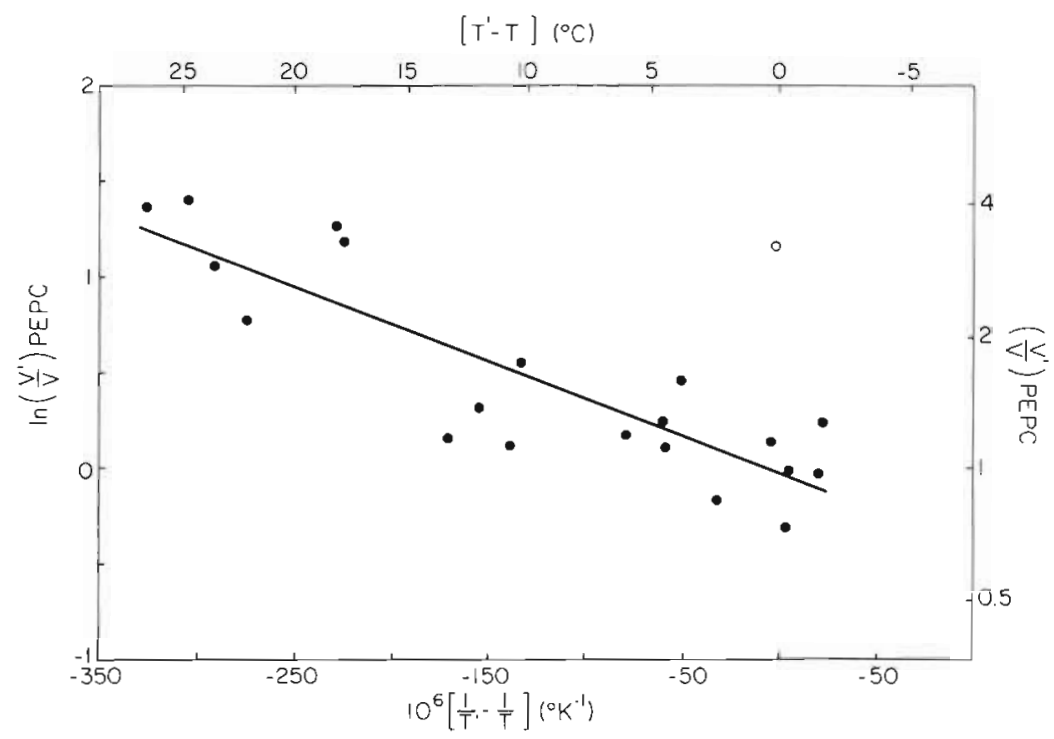

Fig. 5. Modified Arrhenius plot (Equation 3) of PEPC activity in eastern Canadian Arctic marine phytoplankton. Outlying datum (open symbol) was excluded from regression analysis

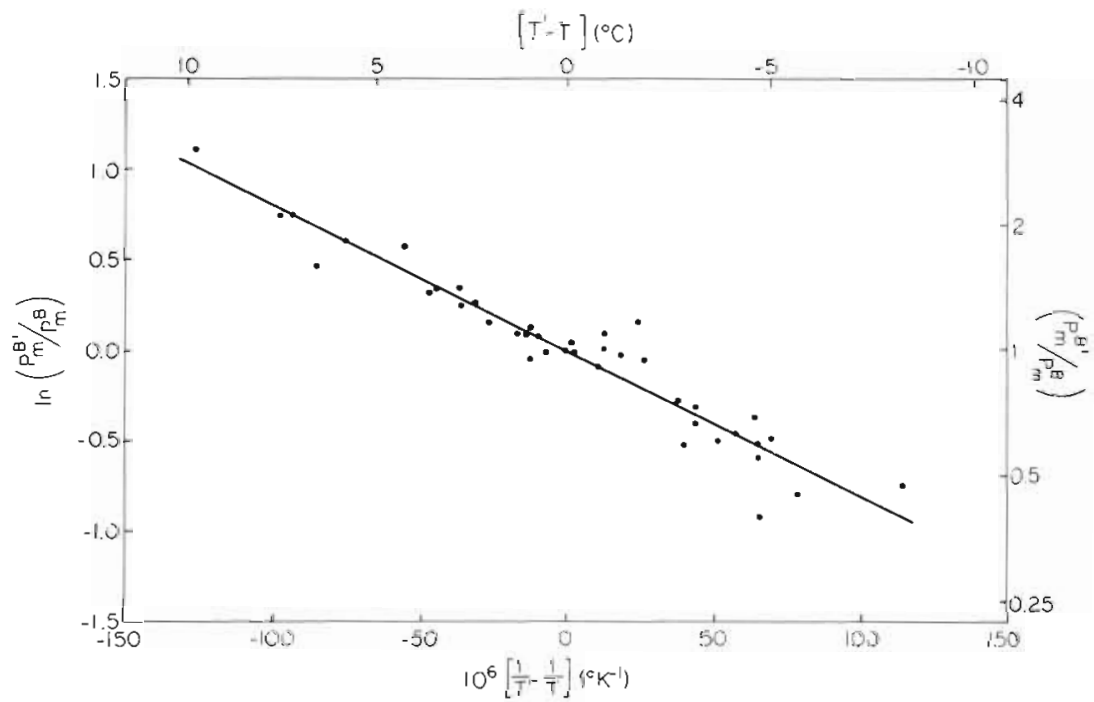

Fig. 6. Modified Arrhenius plot (Equation 3) of photosynthetic capacity in eastern Canadian subarctic (Labrador Sea) marine phytoplankton

PEPC. We have also determined the temperature dependence of $\mathrm{P}_{\mathrm{m}}^{\mathrm{B}}$ for eastern Canadian subarctic (Labrador Sea) phytoplankton (Fig. 6): it was statistically indistinguishable $\left(\mathrm{E}_{\mathrm{a}}=16.0 \pm 0.64 \mathrm{kcal} \mathrm{mol}^{-1}\right)$ from that of $\mathrm{P}_{m}^{\mathrm{B}}$ for Arctic phytoplankton (Fig. 2).

\section{DISCUSSION}

Measurements of the short-term temperature response of inorganic carbon fixation for unicellular algae from high latitude seas (Bunt, 1964; Li and Platt, 1982; Neori and Holm-Hansen, 1982; Jacques, 1983) indicate that such habitats are invariably at temperatures suboptimal for photosynthesis. Extensive studies on higher plants (Berry and Björkman, 1980; Berry and Raison, 1981) suggest that whereas at near optimal temperatures the rate of photosynthesis is principally limited by the capacity of chloroplast membranes for electron transport, it is most likely the activities of enzymes such as RuBPC and fructose bisphosphate phosphatase that are limiting to photosynthesis at suboptimal temperatures. The potential importance of an enzyme in relation to photosynthetic capacity at suboptimal temperature may be indicated by its responsiveness to abrupt shifts in temperature away from that to which the plant is acclimated. Thus, a comparison of the apparent activation energy for photosynthesis and that of possible rate-limiting enzymes may be useful in this context (Berry and Raison, 1981). Björkman and Pearcy (1971) reported that for various species of higher plants, apparent activation energies $\left(E_{\mathrm{a}}\right)$ of photosynthetic capacity and RuBPC activity were in close agreement. Similarly in the present study, of the enzymes examined, only RuBPC consistently exhibited a value of $E_{a}$ equivalent to that of photosynthetic 
capacity (Fig. 2 and 3). These results are consistent with the view that changes in RuBPC activity may be the predominant response of the photosynthetic machinery elicited by temperature changes in the suboptimal range (Berry and Björkman, 1980; Berry and Raison, 1981).

In comparing the temperature response of the $\beta$ carboxylating enzymes (PEPCK and PEPC) and $\mathrm{P}_{\mathrm{m} \text {, we }}^{\mathrm{B}}$ do not imply that these enzymes necessarily function in primary carbon fixation in Arctic phytoplankton. The precise role of $\mathrm{C}_{4}$ metabolic reactions in algae is not fully resolved (Benedict, 1978; Morris, 1980; Kremer, 1981). Our measurements of relatively low apparent activation energies for these enzymes suggest that their role in the control of photosynthetic capacity at low temperatures is less than that of RuBPC.

By themselves, measurements of short-term responses to abrupt shifts in temperature indicate little about the rate of physiological processes that would be found after the organisms had been exposed to a new ambient temperature for an extended period. In general, for ectotherms, the following sequence occurs after a shift from low to high temperature (Prosser, 1964): depending on the abruptness and the extent of the shift, there may be an initial 'shock reaction' leading to an overshoot in metabolic rate; following this, over a period of minutes or hours, a 'stabilized state' prevails during which metabolism is sustained at an elevated rate; finally, over a period of days or weeks, an 'acclimated state' prevails during which compensatory mechanisms have acted to reduce metabolism, at the higher temperature, to a rate near to that occurring before the shift. Measurements such as those in Fig. 2 to 5 and those of Olson (1980) and Neori and Holm-Hansen (1982) most likely pertain to the 'stabilized state'. It is therefore misleading to speak of phytoplankton growth (a property of the acclimated state') being limited by temperature, based on measurements of uptake of nitrogenous nutrients (Olson, 1980) and $\mathrm{CO}_{2}$ (Neori and Holm-Hansen, 1982) as functions of short-term changes in temperature. The results from a laboratory experiment on the marine planktonic diatom Phaeodactylum tricornutum illustrate this point (Li and Morris, 1982): different values of $Q_{10}$ were obtained for growth rate, 'stabilized state' $P_{m}^{B}$ and 'acclimated state' $\mathrm{P}_{\mathrm{m}}^{\mathrm{B}}$.

We now turn our attention to the effect of temperature on the values of $\mathrm{P}_{\mathrm{m}}^{\mathrm{B}}$ in the 'acclimated state'. For this, it is essential that the measurements be made at a saturating (but not inhibiting) irradiance and at the in situ temperature. These requirements were met in our measurements (Fig. 1). We interpret the variation of $\mathrm{P}_{\mathrm{m}}^{\mathrm{B}}$ at any temperature as being due to diel changes (MacCaull and Platt, 1977; Harding et al., 1982), light history (Yentsch and Lee, 1966; Beardall and Morris,
1976), cell size and species composition (Malone, 1971; Durbin et al., 1975; Glover, 1980; Côté and Platt, 1983) and nutrient conditions-(Thomas, 1970; Glover, 1980). To assess the influence of temperature alone, only the highest $\mathrm{P}_{\mathrm{m}}^{\mathrm{B}}$ measured at each temperature $\left(\mathrm{P}_{\mathrm{m}}^{\mathrm{B}}\right)$ should be considered. Operationally, this might be achieved by forming a curve that envelops the scattergram (e.g. Yentsch et al., 1974). The upper limit of our scattergram (Fig. 1) is not sufficiently well-defined to form a unique envelope. Nevertheless, we have indicated a possible form for the envelope (dashed line in Fig. 1) by comparison with similar plots (Yentsch et al., 1974; $\mathrm{Li}, 1980$ ) which indicate a progressive decrease in the dependence of $\mathrm{P}_{\mathrm{m}}^{\mathrm{B}}$ as in situ temperature increases: in other words, the curve 'flattens out'.

For the sake of discussion, we assume for the moment that the dashed curve indeed represents the temperature response of $\hat{P}_{\mathrm{m}}^{\mathrm{B}}$ for eastern Canadian Arctic phytoplankton in the 'acclimated state'. At in situ temperatures $\geq \approx 0{ }^{\circ} \mathrm{C}, \hat{\mathrm{P}}_{\mathrm{m}}^{\mathrm{B}}$ remained constant at $\approx 2 \mathrm{mg}$ $\mathrm{C}$ mg Chl $a^{-1} h^{-1}$. A partial explanation may be that the cellular content of chlorophyll a is reduced at low temperatures (Li, 1980). In Phaeodactylum tricornutum, partial compensation of photosynthesis to low temperature $\left(\geq \approx 10^{\circ} \mathrm{C}\right.$ ) was evident even after the reduction of cellular chlorophyll a had been taken into account; compensation appeared to be related to an increase in RuBPC activity at low temperature in the 'acclimated state' (Li and Morris, 1982). The parallelism between the 'acclimated state' temperature response of arctic phytoplankton and cultures of $P$. tricornutum extends to very low temperatures. In both cases $\left(<0^{\circ} \mathrm{C}\right.$ in the former, $<10^{\circ} \mathrm{C}$ in the latter $), \hat{\mathrm{P}}_{\mathrm{m}}^{\mathrm{B}}$ decreased with temperature (Fig. 1, Li and Morris, 1982). In $P$. tricornutum, there was a decrease in RuBPC activity at $<10^{\circ} \mathrm{C}$. Berry and Björkman (1980) suggested that an improvement in photosynthetic effectiveness at a given low temperature... is likely to require an inordinately large investment in rate-limiting enzymes with only a marginal photosynthetic gain'.

In view of (a) the apparent parallelism between the 'acclimated state' temperature response of Arctic phytoplankton and Phaeodactylum tricornutum, (b) the apparent adaptive nature of RuBPC activity changes in $P$. tricornutum and (c) the apparent importance of changes in RuBPC activity when Arctic phytoplankton are abruptly shifted away from in situ temperature, we suggest that during 'acclimated state', RuBPC activity and $\hat{\mathrm{P}}_{\mathrm{m}}^{\mathrm{B}}$ bear the same relationship to each other in arctic phytoplankton as they do in $P$, tricornutum. However, we must caution that this suggestion remains tentative until a more secure envelope of $\hat{\mathrm{P}}_{\mathrm{m}}^{\mathrm{B}}$ vs. in situ temperature can be established.

Finally, we question whether the values of $\mathrm{P}_{\mathrm{m}}^{\mathrm{B}}$ for 
Arctic phytoplankton are substantially different from those for temperate phytoplankton at low temperatures. In independent compilations of Soviet (Vedernikov, 1975) and Canadian (Harrison and Platt, 1983 which includes the data shown in Fig. 1) measurements in Arctic waters, the most frequently observed values of $\mathrm{P}_{\mathrm{m}}^{\mathrm{B}}$ were from about 0.7 to $1.2 \mathrm{mg} \mathrm{C} \mathrm{mg}$ Chl $a^{-1} \mathrm{~h}^{-1}$; maximum recorded values were about $5.0 \mathrm{mg} \mathrm{C} \mathrm{mg} \mathrm{Chl} a^{-1} \mathrm{~h}^{-1}$. These values are similar to those of temperate phytoplankton at low temperatures (e.g. Williams and Murdoch, 1966; Mandelli et al., 1970; Yentsch et al., 1974; Durbin et al., 1975), suggesting a lack of genotypic adaptation to 'overcome' the limitation of low temperature on enzymatic rates of photosynthesis.

This is supported by the values of specific rates of nutrient uptake by high latitude phytoplankton. If measurements of $\mathrm{CO}_{2}$ and nitrogenous nutrient uptake are made under the condition that incubation and in situ temperatures are the same, specific rates are easily calculated by normalizing the uptake rates to phytoplankton biomass in units of carbon and nitrogen respectively. In cases where this has been done (e.g. Holm-Hansen et al., 1977; Slawyk, 1979; Olson, 1980; El-Sayed and Taguchi, 1981; Harrison et al., 1982; Neori and Holm-Hansen, 1982), the specific rates are almost always equal to or less than the specific rates of growth (cell divisions) predicted by Eppley (1972) for temperate phytoplankton at low temperatures. Caution is required to interpret such comparisons because the critical assumption of balanced growth (rates of nutrient uptake and cell division are equal) is probably met only infrequently under natural conditions (Eppley, 1981). Nevertheless, even when division rates are directly measured in culture, growth of high latitude algal isolates (Bunt, 1967; Seaburg et al., 1981; Palmisano and Sullivan, 1982; Jacques, 1983; van Baalen and O'Donnell, 1983) is not very different from growth, at low temperatures, of 'cold water species' isolated from temperate waters (Smayda, 1969; Durbin, 1974; Baars, 1981, 1982). This contrasts with the distinctly different temperature response of growth between temperate and tropical isolates (Braarud, 1961; Guillard and Kilham, 1977; Hulburt, 1982).

A plausible explanation to account for low photosynthetic rates in high latitude seas (and therefore also for the common observations of the substantial discrepancy between the temperature in situ and that at which photosynthesis is optimized) is that large increases in enzymes at low temperatures might be energetically cost ineffective (Berry and Björkman, 1980): this remains to be tested.

Acknowledgements. We thank W. G. Harrison for helpful discussions concerning assimilation numbers. Data from numerous cruises to the eastern Canadian Arctic were collected and collated with assistance from many technicians and summer students: we are grateful to all of them, especially B. D. Irwin.

\section{LITERATURE CITED}

Appleby, G., Colbeck, J., Holdsworth, E. S., Wadman, H (1980). $\beta$-carboxylation enzymes in marine phytoplankton and isolation and purification of pyruvate carboxylase from Amphidinium carterae (Dinophyceae). J. Phycol. 16: 290-295

Baars, J. W. M. (1981). Autecological investigation on marine diatoms. 2. Generation times of 50 species. Hydrobiol. Bull. 15: 137-151

Baars, J. W. M. (1982). Autecological investigation on marine diatoms. 3. Thalassiosira nordenskioeldii and Chaetoceros diadema. Mar Biol. 68: 343-350

Beardall, J., Morris, I. (1976). The cuncept of light intensity adaptation in marine phytoplankton: some experiments with Phaeodactylum tricornutum. Mar. Biol. 37: 377-387

Benedict, C. R. (1978). Nature of obligate photoautotrophy. Ann. Rev. Plant Physiol. 29: 67-93

Berry, J., Björkman, O. (1980). Photosynthetic response and adaptation to temperature in higher plants. Ann. Rev. Plant Physiol. 31: 491-543

Berry, J., Raison, J. J. (1981). Responses of macrophytes to temperature. In: Lange, O. L., Nobel, P. S., Osmond, C. B., Ziegher, H. (ed.) Physiological plant ecology I. Responses to the physical environment, Vol. 12.4. Springer-Verlag, Berlin, p. 277-338

Björkman, O., Pearcy, R. W. (1971). Effect of growth temperature on temperature dependence of photosynthesis in vivo and on $\mathrm{CO}_{2}$ fixation by carboxydismutase in vitro in $\mathrm{C}_{3}$ and $\mathrm{C}_{4}$ species. Carnegie Institution of Washington Yearbook 70: $511-520$

Braarud, $T$ (1961). Cultivation of marine organisms as a means of understanding environmental influences on population. In: Sears, M. (ed.) Oceanography. American Association for the Advancement of Science, Washington, p. 271-298

Bunt, J. S. (1964). Primary productivity under sea ice in Antarctic waters. 2. Influence of light and other factors on photosynthetic activities of Antarctic marine microalgae. Antarct. Res. Ser. 1: 27-31

Bunt, J. S. (1967). Some characteristics of microalgae isolated from Antarctic sea ice. Antarct. Res. Ser 11: 1-14

Côté, B., Platt, T (1983). Day-to-day variations in the springsummer photosynthetic parameters of coastal marine phytoplankton. Limnol. Oceanogr 28: 320-344

Durbin, E. G. (1974). Studies on the autecology of the marine diatom Thalassiosira nordenskioeldii Cleve. I The influence of day-length, light intensity, and temperature on growth. J. Phycol. 10: 220-225

Durbin, E. G., Krawiec, R. W., Smayda, T. J. (1975). Seasonal studies on the relative importance of different size fractions on phytoplankton in Narragansett Bay (USA). Mar Biol. 32: 271-287

El-Sayed, S. Z., Taguchi, S. (1981). Primary production and standing crop of phytoplankton along the ice-edge in the Weddell Sea. Deep Sea Res. 28 A 1017-1032

Eppley, R. W. (1972). Temperature and phytoplankton growth in the sea. Fish. Bull. U.S. 70: 1063-1085 
Eppley, R. W (1981) Relations between nutrient assimilation and growth in phytoplankton with a brief review of estimates of growth rate in the ocean. In: Platt, $T$ (ed.) Physiological bases of phytoplankton ecology. Canadian Bulletin of Fisheries and Aquatic Sciences, 210, Ottawa, p. $251-263$

Glover, H. E. (1980). Assimilation numbers in cultures of marine phytoplankton. J. Plankton Res. 2: 69-79

Graham, D., Patterson, B. D. (1982). Responses of plants to low, non-freezing temperatures: proteins, metabolism, and acclimation. Ann. Rev. Plant Physiol. 33: 347-372

Guillard, R. R. L., Kilham, P. (1977). The ecology of marine planktonic diatoms. In: Werner, D. (ed.) The biology of diatoms. University of California Press, Berkeley and Los Angeles, p. $372-469$

Harding, L. W. Jr., Prézelin, B. B., Sweeney, B. M., Cox, J. L. (1982). Diel oscillations of the photosynthesis-irradiance (P-I) relationship in natural assemblages of phytoplankton. Mar. Biol. 67: 167-178

Harrison, W G., Platt, T (1983). Photosynthetic characteristics of phytoplankton in the eastern Canadian Arctic. Proceedings of the Symposium on Biology of Northern Oceans, International Union of Biological Sciences, Ottawa, Canada

Harrison, W. G., Platt, T., Irwin, B. (1982). Primary production and nutrient assimilation by natural phytoplankton populations of the eastern Canadian Arctic. Can. J. Fish. Aquat. Sci. 39: 335-345

Holm-Hansen, O., El-Sayed, S. A., Franceschini, G. A., Cuhel, R. L. (1977). Primary production and the factors controlling phytoplankton growth in the Southern Ocean. In: Llano, G. A. (ed.) Adaptations within Antarctic ecosystems. Gulf Publication Co., Houston, Texas, p. 11-50

Holm-Hansen, O, Lorenzen, C. J., Holmes, R. W., Strickland, J. D. H. (1965). Fluorometric determination of chlorophyll. J. Cons. perm. int. Explor Mer 30: 3-15

Hulburt, E. M. (1982). The adaptation of marine phytoplankton species to nutrient and temperature. Ocean Sci. Eng. $7: 187-228$

Jacques, G. (1983). Some ecophysiological aspects of the Antarctic phytoplankton. Polar Biol. 2: 27-33

Kremer, B. P. (1981). Dark reactions of photosynthesis. In: Platt, T. (ed.) Physiological bases of phytoplankton ecology. Can. Bull Fish. Aquat. Sci.: 210, Ottawa, p. 44-54

Li, W K. W. (1980). Temperature adaptation in phytoplankton: cellular and photosynthetic characteristics. In: Falkowski, P. G. (ed.) Primary Productivity in the Sea. Plenum Press, New York and London, p. 259-279

Li, W. K. W., Morris, I. (1982). Temperature adaptation in Phaeodactylum tricornutum Bohlin: photosynthetic rate compensation and capacity. J. exp. mar biol. Ecol. 58: $135-150$

Li, W. K. W., Platt, T. (1982). Distribution of carbon among photosynthetic end-products in phytoplankton of the eastern Canadian Arctic. J. Phycol. 18: 466-471

MacCaull, W. A., Platt, T (1977). Diel variations in the photosynthetic parameters of coastal marine phytoplankton. Limnol. Oceanogr. 22: 723-731

Malone, T. C. (1971). The relative importance of nannoplankton and netplankton as primary producers in tropical oceanic and neritic phytoplankton communities. Limnol. Oceanogr. 16: 633-639
Mandelli, E. F., Burkholder, P. R., Doheny, T E., Brody, R. (1970). Studies of primary productivity in coastal waters of southern Long Island, New York. Mar Biol. 7. 153-160

Morris, I. (1980). Paths of carbon assimilation in marine phytoplankton. In: Falkowski, P. G. (ed.) Primary productivity in the sea. Plenum Press, New York and London, p. $139-159$

Neori, A. Holm-Hansen, O. (1982). Effect of temperature on rate of photosynthesis in antarctic phytoplankton. Polar Biol. 1 33-38

Olson, R. J. (1980). Nitrate and ammonium uptake in Antarctic waters. Limnol. Oceanogr 25: 1064-1074

Palmisano, A. C., Sullivan, C. W. (1982). Physiology of sea ice diatoms. I. Response of three polar diatoms to a simulated summer-winter transition. J. Phycol. 18: 489-498

Patterson, D. T. (1980). Light and temperature adaptation. In: Hesketh, J. D. (ed.) Predicting photosynthesis for ecosystem models, Volume 1. Chemical Rubber Co. Press, Boca Raton, Florida, p. 205-235

Prosser, C. L. (1964). Perspectives of adaptation - theoretical aspects. In: Dill, D. B., Adolph, E. R., Wilber, C. G. (ed.) Handbook of physiology, Section 4. Adaptation to the environment. American Physiological Society, Washington, p. 11-25

Seaburg, K. G., Parker, B. C., Wharton, R. A. Jr., Simmons, G M. Jr (1981). Temperature-growth responses of algal isolates from Antarctic oases. J. Phycol. 17: 353-360

Slawyk, G. (1979). ${ }^{13} \mathrm{C}$ and ${ }^{15} \mathrm{~N}$ uptake by phytoplankton in the Antarctic upwelling area: results from the Antiprod I cruise in the Indian Ocean sector Aust. J. mar. Freshwat. Res. 30: $431-448$

Smayda, T J. (1969). Experimental observations on the influence of temperature, light and salinity on cell division of the marine diatom Detonula confervacea (Cleve) Gran. J. Phycol. 5: 150-157

Smith, J. C., Platt, T., Harrison, W. G. (1983). Photoadaptation of carboxylating enzymes and photosynthesis during a spring bloom. Prog. Oceanogr 12: 425-459

Thomas, W. H. (1970). On nitrogen deficiency in tropical Pacific oceanic phytoplankton: photosynthetic parameters in poor and rich water. Limnol. Oceanogr, 15: 380-385

Van Baalen, C., O'Donnell, R. (1983). Isolation and growth of psychrophilic diatoms from the ice-edge in the Bering Sea. J. gen. Microbiol. 129: 1019-1023

Vedernikov, V I. (1975). Dependence of the assimilation number and concentration of chlorophyll $a$ on water productivity in different temperature regions of the world ocean. Oceanology 15: 482-485

Williams, R. B., Murdoch, M. B. (1966). Phytoplankton production and chlorophyll concentration in the Beaufort Channel, North Carolina. Limnol. Oceanogr. 11: 73-82

Yentsch, C. S., Menzel, D. W. (1963). A method for the determination of phytoplankton chlorophyll and phaeophytin by fluorescence. Deep Sea Res. 10: 221-231

Yentsch, C. S., Lee, R. W (1966). A study of photosynthetic light reactions, and a new interpretation of sun and shade phytoplankton. J. mar. Res. 24: 319-337

Yentsch, C. S., Yentsch, C. M., Strube, L. R., Morris, I. (1974). Influence of temperature on the photosynthetic efficiency in natural populations of marine phytoplankton. In: Gibbons, J. W., Sharitz, R. R. (ed.) Thermal ecology. Atomic Energy Commission, Oak Ridge, Tennessee, p. 508-517 